Provided for non-commercial research and education use. Not for reproduction, distribution or commercial use.

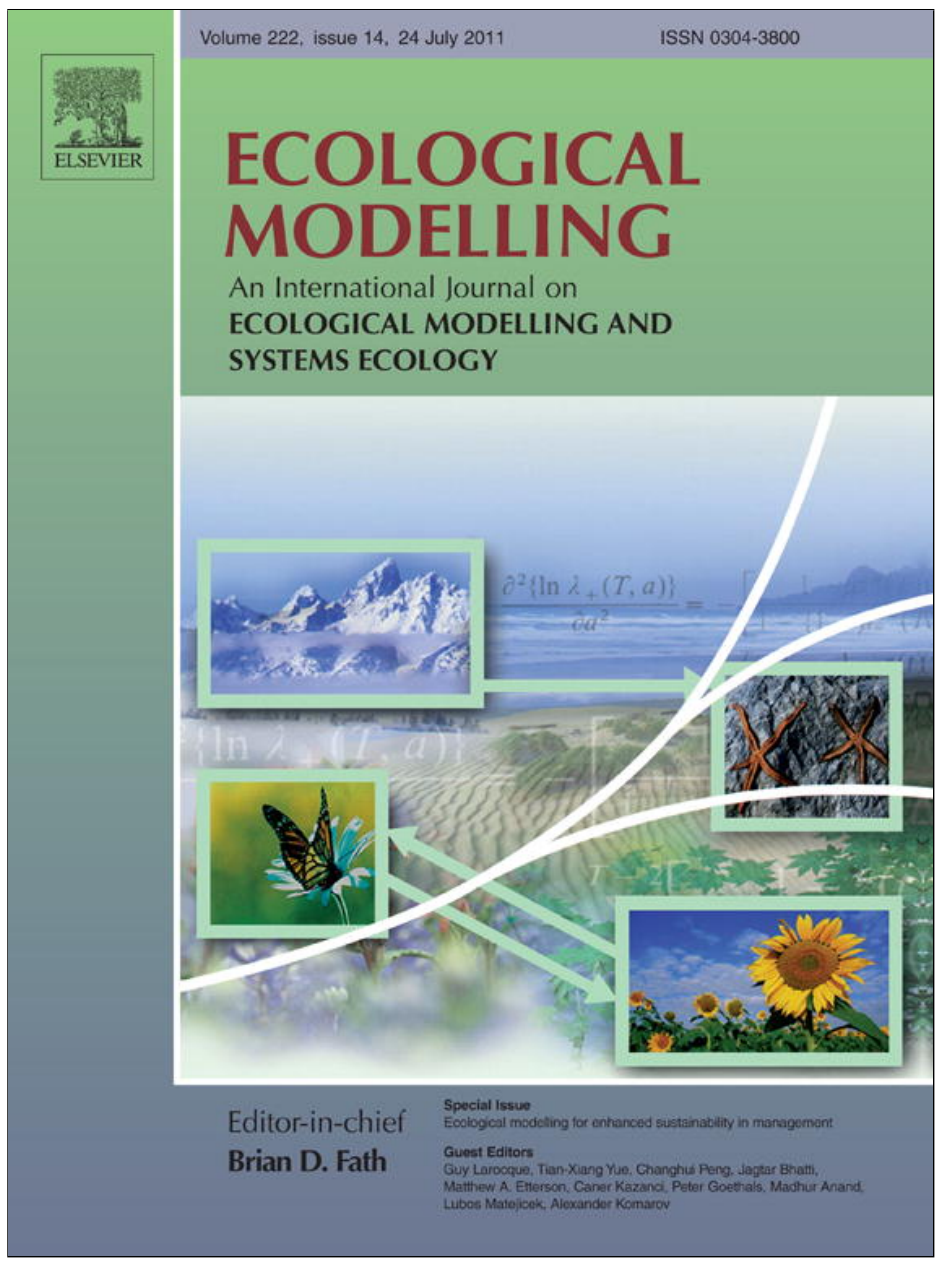

This article appeared in a journal published by Elsevier. The attached copy is furnished to the author for internal non-commercial research and education use, including for instruction at the authors institution and sharing with colleagues.

Other uses, including reproduction and distribution, or selling or licensing copies, or posting to personal, institutional or third party websites are prohibited.

In most cases authors are permitted to post their version of the article (e.g. in Word or Tex form) to their personal website or institutional repository. Authors requiring further information regarding Elsevier's archiving and manuscript policies are encouraged to visit:

http://www.elsevier.com/copyright 


\title{
An inverse model for the analysis of the Venice lagoon food web
}

\author{
D. Brigolin ${ }^{\mathrm{a}, *}$, C. Savenkoff ${ }^{\mathrm{b}}$, M. Zucchetta ${ }^{\mathrm{a}}$, F. Pranovi ${ }^{\mathrm{a}}$, P. Franzoi $^{\mathrm{a}}$, P. Torricelli $^{\mathrm{a}}$, R. Pastres $^{\mathrm{a}}$ \\ a Department of Environmental Sciences, Informatics and Statistics, Università Ca' Foscari Venezia, Dorsoduro 2137, 30123 Venezia, Italy \\ ${ }^{\mathrm{b}}$ Pêches et Océans Canada, Institut Maurice-Lamontagne, 850 route de la Mer, Mont-Joli, Québec G5H 3Z4, Canada
}

\section{A R T I C L E I N F O}

\section{Article history:}

Available online 3 May 2011

\section{Keywords:}

Food web

Inverse models

Mass balance models

Organic detritus

Trophic fluxes

Venice lagoon

\begin{abstract}
A B S T R A C T
A steady-state model of the Venice lagoon food web was constructed, based on a comprehensive set of data, which were collected in the years 2001-2005. Energy flows were estimated by means of an inverse methodology of constrained optimization based on the Minimum Norm criterion, i.e. on the minimization of both the sum of squares of the residuals and of the sum of squares of energy flows. The solution was constrained by a set inequalities, which were derived from general eco-physiological knowledge and site specific data on energy flows. The trophic network was represented by thirty-two nodes, including singlespecies compartments for the species of high economical or ecological relevance. Mass balance equations were weighted, in order to obtain meaningful results in presence of large differences, up to 5 orders of magnitude, among biomasses. A perturbation technique was applied, with the purpose of reducing the risk of finding solutions heavily affected by the set of constraints and of obtaining a more robust representation of the energy flows. The main patterns of energy flow are consistent with those obtained in previous attempts at modelling the Venice lagoon food web. Micro- and macro-phytobenthos account for the largest fraction of the primary production. Energy is then transferred towards higher trophic levels by means of two main pathways: the recycling of dead biomass through the detritus compartment and the direct consumption by grazers. The first pathway is the most important and accounts for approximately two/thirds of the energy transferred to the second trophic level.
\end{abstract}

(C) 2011 Elsevier B.V. All rights reserved.

\section{Introduction}

In spite of the increasing anthropic pressure (Veneto Region Statistics Database, 2010, http://statistica.regione.veneto.it), the Venice lagoon ecosystem is still supporting diverse human activities, such as tourism, harbour, fishery, which can be regarded as "ecosystem services" (sensu Costanza et al., 1997). Preserving this "natural capital", represents a huge management challenge, since, at present, the sediment export is not compensated by the inputs coming from the tributaries and the atmospheric downfall. As a result, the existence of typical habitats, such as salt marshes, mud flats, etc., is being severely threatened: as an example, in the last 60 years, $40 \%$ of the salt marshes has disappeared (Venice Water Authority, 2010), many secondary canals are being progressively filled, and the depth of flat shallow areas is, in general, increasing. In order to invert this trend, the Venice Water Authority is designing a comprehensive restoration plan, which includes the reconstruction of the main morphological structures and the protection of the existing ones. Within this context, it is mandatory to understand how such interventions could affect the whole ecosystem functioning. A class of models widely used for this purpose are

\footnotetext{
* Corresponding author.

E-mail address: brigo@unive.it (D. Brigolin).
}

steady state food web models, which are often applied to coastal ecosystems to quantify mass and energy fluxes associated with trophic interactions between different compartments of a food web (Belgrano et al., 2005). These models generate a snapshot of the trophic network at one moment in time, which is consistent with the set of input data. However, they can be subsequently used for understanding how the ecosystem would respond to changes in the external fluxes, such as fishery export, or internal ones, such as organic matter sedimentation and resuspension. Food web models have been already applied to the Venice lagoon ecosystem. Carrer and Opitz (1999) first developed a 16-compartments network to study the ecosystem of a specific site of the lagoon, and then Carrer et al. (2000) simplified this model to 12-compartments and coupled it with a bioaccumulation model for an ecotoxicological study. Libralato et al. (2002) implemented a 27-compartments model which was applied to two different lagoon habitats, and was recently coupled with a biogeochemical model, in an attempt to achieve an end-to-end representation of the ecosystem dynamics (Libralato and Solidoro, 2009). The same food-web model was adapted by Pranovi et al. (2003) to study the impacts of clam dredging on the lagoon ecosystem. However, all these modelling attempts were based on data sets collected in the 1990s, when the ecosystem was shifting from a condition of severe eutrophication and massive presence of macroalgae to a mesotrophic condition. Furthermore, the rapid increase of fishery activity targeting the 
bivalve Ruditapes philippinarum in the 1990s, was changing the sedimentation-resuspension pattern in some areas of the lagoon.

In order to detect the effect of these changes on the ecosystem structure and functioning, a new and more comprehensive data set was assembled (see Appendix A), which can be mostly referred to the year 2003. Such data set allowed the identification and modelling of the fluxes among a higher number of compartments, thirty-two, including the main target species of the artisanal fishery and some species with key ecological role.

The food web model was constructed using a method belonging to the class of so-called Inverse Model, IM (Vézina and Platt, 1988), according to which the trophic network is balanced, under a set of constraints, on the basis of an objective least-squares criterion for the minimization of the residuals, i.e. of the differences between the left hands and the right hands of the steady-state mass balance equations. IM have been widely used in ecosystem modelling during the last years, as they allow one to consistently estimate a large number of unknown flows from a relatively small number of observations (Leguerrier et al., 2003; Vézina et al., 2004; Savenkoff et al., 2007a,b) concerning standing biomasses, diets and flows.

This method leads to select a unique solution, i.e. a well defined set of flows, out of the space of potential solutions by means of a constrained optimization, based on a minimum-norm principle. IM allows one to combine compartmental mass balance equations, with data equations and eco-physiological constraints on the energy flows (inequalities) (Savenkoff et al., 2004): the latter can be defined on the basis of the general literature and of site-specific knowledge concerning the functioning of a given ecosystem. Therefore, IM presents the additional advantage of obtaining, from a mechanistic model, estimates of energy flows among compartments which are consistent with both general ecological principles and site specific knowledge concerning, for example, dietary preferences, fishery landings etc. Furthermore, the use of a completely specified and repeatable protocol, which assures that there is a one-to-one correspondence between the set of input data and constraints and the model output, allows one to implement Monte Carlo based methods for the assessment of the robustness of the solutions and for the estimation of the uncertainty of key outputs, in relation to that of a specified subset of input data (Savenkoff et al., 2007a).

In this study, the IM was used for constructing a mass balance model for the ecosystem of the Venice lagoon, with the specific objectives of:

(i) characterizing the structure and functioning of the lagoon food web in the year 2003 and comparing it with previous lagoon food web models, in order to detect trends in the ecosystem evolution;

(ii) investigating the role of the organic detritus in sustaining the ecosystem productivity and fishery.

\section{Materials and methods}

The IM developed within this work seeks the solution to the inverse problem by means of an objective method for constrained optimization, based on the minimum-norm principle. This method was initially adapted from physical sciences by Vézina and Platt (1988) for the reconstruction of planktonic food webs. Savenkoff et al. $(2004,2007 a)$ extended it to the whole ecosystem network. Details on the solution algorithm are reported in Vézina and Platt (1988) and Savenkoff et al. (2004). This section focuses on equations and constraints used within the present work, which differ slightly from those employed in previous studies (Savenkoff et al., 2004, 2007a). The model structure and its parameterization are described in detail in the next section.
In order to estimate unknown flows, IM combines mass balance equations with: (i) data equations and (ii) constraints on the flows, expressed as inequalities. The mass balance equations specify that, for each compartment, the sum of inflows is balanced by the sum of outflows, a net change in the biomass variable, $\Delta B_{i}$ and a residual term, $\varepsilon$. No change in biomass, $\Delta B_{i}=0$, during the studied time period was assumed (steady-state assumption). Production was assumed equal to the biomass lost to fishing, predation, natural mortality other than predation, hereafter termed other mortality causes, and net migration (migration out of or into the study area, food intake of predators that are not part of the system, etc.). Other mortality causes could include other natural causes of death such as disease or could reflect unsuspected processes occurring in the ecosystem, such as misreported catch, unsuspected migration or other processes not accounted for in the model (Savenkoff et al., 2004). The mass balance equations computed through the optimization algorithm has not to be exactly balanced, that is, the sum of the inputs and outputs for each compartment does not necessarily equal zero. The differences are termed residuals, and are represented by the error term $\varepsilon$. Residuals are assumed to be randomly and independently distributed with uniform variance (Vézina and Platt, 1988). The general mass balance equation for individual compartments can be written as:

Consumption - respiration - egestion - fishing mortality

- predation - other mortality - net migration $=0+\varepsilon$

Data equations may also be used for fixing the value of certain flows or combinations of flows: in our application, for example, data equations were used for specifying fishery landings and a sub-set of diet coefficients. Data equations are treated by the constrained optimization method as mass-balances equations: therefore a solution is sought which minimizes the sum of squares of the residuals between input data and model output.

In general, field data do not allow one to completely specify all flows. As a result, the system of equations is underdetermined, since the number of flows to be solved largely exceeded the number of independent mass balance relations. In order to obtain a solution which is consistent with general eco-physiological knowledge and site-specific information about feeding preferences, a set of additional constraints can be defined (Savenkoff et al., 2004). As an example, flows must be positive and ratios of flows should fall within certain ranges to satisfy basic metabolic efficiencies of assimilation and growth.

Furthermore, the constrained optimization was performed using the weighting scheme proposed in Vézina and Savenkoff (1999), according to which data equations and unknown flows are multiplied by the inverse of the variances as the weights for energy balance (Appendixes B and C). The use of weights limits the influence of compartments with high energy stocks on the solution. Therefore, it is particularly useful when the food web is likely to include compartments with very different biomasses.

\subsection{Random perturbations of input data}

In many food web studies only one steady-state solution is computed, and uncertainty cannot be considered in the subsequent interpretation of the results (Bundy, 2005; Morissette et al., 2009). Within this work the solution's robustness to uncertainty in input data was assessed based on the random perturbation methodology proposed by Savenkoff et al. (2007a). A sub-set of input data was considered in this analysis, namely the fishery landings for the main target species. Each nominal value for landings, $x_{i}$, was replaced by a "synthetic" input data, $x_{i}+r_{n} \mathrm{SD}_{i}$, where $r_{n}$ is a real number randomly chose between -1 and 1 , assuming an uniform distribution. 
The inverse analysis was recalculated for each set of synthetic input data. The solution presented in the next section is the mean of the solutions obtained from 31 model runs: 30 synthetic solutions originated by random perturbations of the initial data, and one solution without perturbation (the nominal solution).

A second result of the perturbation methodology proposed by Savenkoff et al. (2007a) is related to the reduction of active, or "sticky", constraints. These constraints are met in correspondence of those flows which are bound to the upper or lower limit of the interval set by inequalities. The problem of active constraints is originated by the minimum norm criterion on which the inverse method is based. Savenkoff et al. (2007a) suggest that a large number of active constraints indicate that the optimum may not have been found and that the solution was determined by a priori bounds rather than by patterns in the data. These authors suggested that many realizations of the data (mean of different iterations) allows to construct a solution that is less sensitive to the constraints and give more confidence in the results and their interpretation.

\subsection{Trophic level, ecotrophic efficiency and indexes}

Food web models represent a set of complex relationships among many compartments. In order to summarize the results and obtain useful information about ecosystem functioning, it is useful to aggregate compartments into trophic levels and compute synthetic indexes. The trophic level of each compartment $\left(\mathrm{TL}_{i}\right)$ is a dimensionless index based on Lindeman's (1942) concept of trophic levels. A trophic level of one is assigned to primary producers and detritus compartments. For other species, $\mathrm{TL}_{i}$ is calculated as:

$\mathrm{TL}_{i}=1+\left(\sum_{i} p_{j} \cdot \mathrm{TL}_{j}\right)$

where $p_{j}$ is the proportion (in mass) of each prey compartment in the diet of its predator $i . \mathrm{TL}_{j}$ is the trophic level of each prey compartment $j$. Similarly, the mean trophic level of fishery catches $\left(\mathrm{TL}_{\mathrm{C}}\right)$ is calculated from:

$\mathrm{TL}_{\mathrm{C}}=\sum_{i}\left(\mathrm{TL}_{i}\left(\frac{Y_{i}}{\sum Y}\right)\right)$

where $Y_{i}$ is the total landings of species $i$ (here in $\mathrm{kJ} \mathrm{m}^{-2} \mathrm{~d}^{-1}$ ), $\Sigma Y$ is the sum of landings for all species, and $\mathrm{TL}_{i}$ is the trophic level for species $i$.

The ecotrophic efficiency, EE, is a synthetic index defined as the fraction of the production that is either passed up the food web or exported. EE of detritus compartments is defined as the ratio of what flows out to what flows into the compartment (Christensen and Pauly, 1992). Under the steady state assumption, this ratio should be equal to 1 .

The Total System Throughput (TST), equal to the sum of all flows, is an indicator of ecosystem activity (Ulanowicz, 1986).

\section{Model implementation}

The lagoon of Venice is a shallow water body covering an area of nearly $500 \mathrm{~km}^{2}$, with an average depth of approximately $1 \mathrm{~m}$, except for the deeper navigable channels (depths $<15 \mathrm{~m}$; Fig. 1). The system is connected to the Northern Adriatic Sea through three inlets (500-1000 $\mathrm{m}$ wide and $15-50 \mathrm{~m}$ deep), with a yearly averaged exchange of $8000 \mathrm{~m}^{3} \mathrm{~s}^{-1}$ (Gačić et al., 2005). Water renewal is on the order of a few days for the area closest to the inlets and up to $30 \mathrm{~d}$ for the inner area (Cucco and Umgiesser, 2006). The drainage basin covers an highly populated and intensively farmed area, and its loads in 2003 accounted for $4 \times 10^{6} \mathrm{~kg} \mathrm{y}^{-1}$ of nitrogen and $0.25 \times 10^{6} \mathrm{~kg} \mathrm{y}^{-1}$ of phosphorus (ARPAV, 2007). Many types

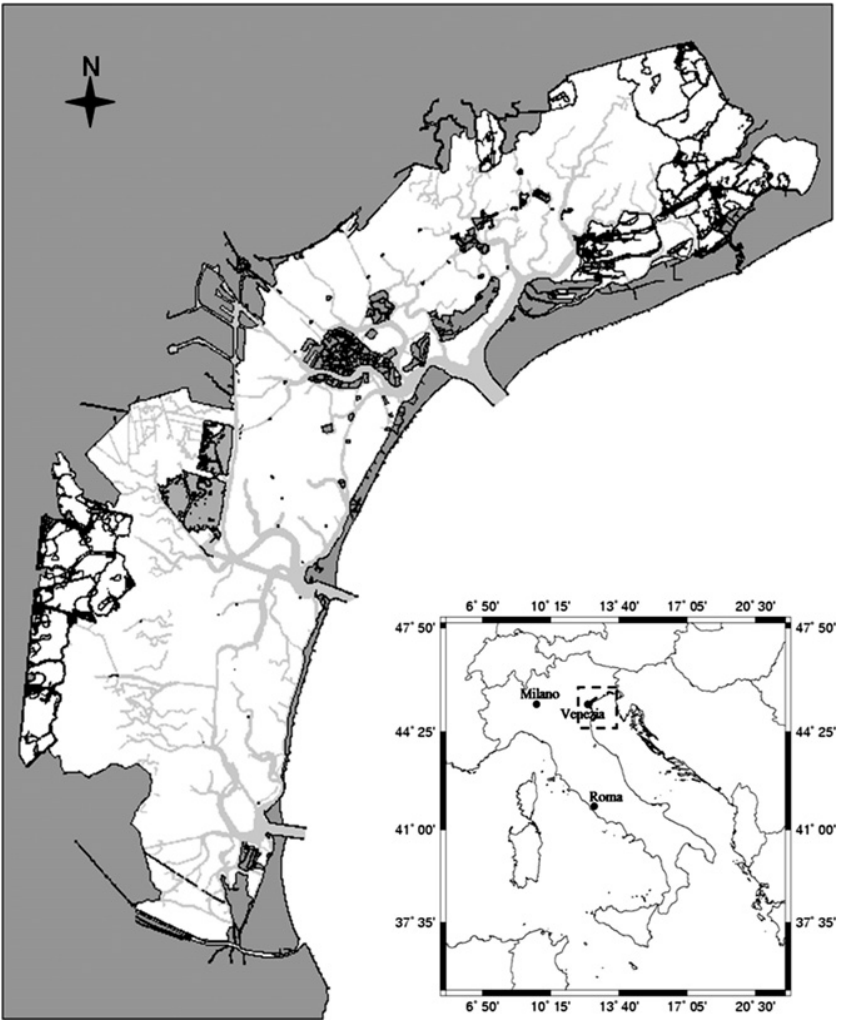

Fig. 1. Study area: the lagoon of Venice (Italy)

of habitats, sub-tidal and intertidal, are present, such as seagrass meadows, mud flats, sand flats and salt marshes, each one with a different functional role for migrant and resident fish fauna (Franco et al., 2006b; Franzoi et al., 2010). The type of habitat is recognised also to be an important driver for benthic secondary production (Tagliapietra et al., 2007).

References for the sources of data used for constructing the food web model are summarized in Appendix A, Table A1 (Brey, 2001; Buia et al., 2000; Cavraro, 2007; Celussi et al., 2009; Coll et al., 2007; Consorzio Venezia Nuova, 2003, 2005a,b; Danovaro and Fabiano, 1997; Facca and Sfriso, 2007; Facca et al., 2009; Franco et al., 2006a; Froese and Pauly, 2002; Jørgensen et al., 1991; Sfriso and Facca, 2007; Sfriso and Ghetti, 1998; Sorokin and Giovanardi, 1995). The dataset covers areas of the lagoon characterized by different residence times and productivities. Data were collected between 2001 and 2005, although for 12 over 23 compartments data were sampled in 2003, from May to October. During this period a comprehensive set of data concerning macrophytes, phytoplankton, and microphytobenthos was collected at 465 stations homogenously distributed in the lagoon. Epiphyte biomass was estimated by assuming a constant percentage of coverage of seagrass shoots, which was determined on the basis of a field experiment carried out in the Venice lagoon (Curiel, pers. comm.). Production values for macrophytes, microphytobenthos, phytoplankton and bacterioplankton are representative for the whole spring-summer time period. Biomasses of benthic species were sampled in summer 2003 at 60 stations in the lagoon. Production values were estimated by using a set of empirical models recently reviewed by Tagliapietra et al. (2007), taking $25^{\circ} \mathrm{C}$ as the average temperature for the May-October period (Corila, 2009). Fish biomasses, except for small gobies and pipefish, were estimated by applying a Virtual Population Analysis to market data Venice and Chioggia 2002-2005. According to Pranovi et al. (2003), data were pre-processed in order to estimate total catches from the lagoon of Venice in the 
Spring-Summer semester. The same 2002-2005 Venice and Chioggia market data were used also for estimating the Fishery landings. Biomasses for small gobies and pipefish were, instead, estimated from field surveys conducted during spring-summer 2002. Very little is known about fish production in the Venice lagoon; production $(P)$ and consumption $(Q)$ were thus estimated by multiplying biomass $(B)$ by $P / B$ or $Q / B$ ratios reported in the literature. The values used are those reported by Carrer and Opitz (1999) for a restricted area of the Venice lagoon and from Auteri et al. (1993) for the Orbetello lagoon (Tyrrhenian Sea).

Diet compositions for most fish and birds were based on samples from the Venice lagoon and species-specific knowledge from Mediterranean wetlands (Ass. Faunisti Veneti, 2004; Franzoi et al., 2005). For benthic species, the average diet preferences $\left(D C_{i j}\right)$ were based on an expert opinion (Pranovi, pers. comm.). For each proportion of prey $i$ consumed by the group $j$, lower and upper limits $\left(\mathrm{DC}_{\mathrm{MIN} i j}=\mathrm{DC}_{i j}-\mathrm{SD}, \mathrm{DC}_{\mathrm{MAX} i j}=\mathrm{DC}_{i j}+\mathrm{SD}\right)$ were introduced in the model as diet constraints. In the case of macrobenthos diet constraints were based on expert opinion (Pranovi, pers. comm.). Water column and sediment organic detritus were estimated from two datasets collected at different sites of the lagoon in 2001 and 2003 (see Table A1).

Based on the comprehensive data set described above, the Venice lagoon food web was represented by means of 32 nodes (Table 1). Each node, or compartment, consisted of a single-species, a group of species or a non-living pool of organic detritus. The choice to focus, in certain instances, on single-species (e.g. Crangon crangon, $R$. philippinarum) was based on the ecological and commercial significance of the species, as well as on data availability. Benthic primary producers and plankton community were aggregated into 5 and 3 compartments, respectively. Species of benthic consumers were aggregated in 8 compartments on the basis of the similarity in size and feeding ecology. Nekton was represented by means of 12 compartments: different life-stages of grass goby, mullets, European seabass and gilthead seabream were separated based on diets. Fish juveniles fed mainly on invertebrates whereas larger fish resulted to be piscivorous. Seabirds species were aggregated in two compartments. Two pools of organic detritus were distinguished in the network: water column detritus, WCD, and sediment detritus, SPD. The set of data equations included also the fishery landings (Table A2) and diet proportions with either low observed values, $<0.5 \%$, and low uncertainty, $\mathrm{SD}<1.5 \%$, or whose coefficient of variation was high, $\mathrm{CV}>600 \%$ (Appendix C).

As a result, 32 mass balances and 28 data equations (Appendix C) were specified, yielding to a total of 60 equations, which had to be solved for 310 unknown flows (Appendix B). As expected, the system was strongly underdetermined, since the number of flows to be solved largely exceeded the number of independent mass balance relations. The set of constraints used to define the space of solutions is given in (Appendix D; Sfriso et al., 2005; Vézina and Pace, 1994; Winberg, 1956). Based on general ecological knowledge, each flow was taken to be non-negative and flows, or ratios of flows, were assumed to fall within certain ranges, in order to satisfy basic metabolic requirements. Minimum and maximum values were imposed for production, consumption and for those feeding relations which were not already specified in the data equations, see Table A3. To this category belonged the production and consumption values not estimated from local field studies, and the

Table 1

Compartment used to represent the Venice lagoon trophic network.

\begin{tabular}{|c|c|c|c|}
\hline Compartment & Code & Description & Sub-system ( $\mathrm{B} \equiv$ benthic; $\mathrm{P} \equiv$ pelagic $)$ \\
\hline Microphytobenthos & Mpb & Amphora, Cocconeis, Navicula, Nitschia, Thalassiosira sp. & B \\
\hline Seagrasses & $\mathrm{Sg}$ & Zostera marina, Nanozostera noltii, Cymodocea nodosa & B \\
\hline Macroalgae & Ma & $\begin{array}{l}\text { Vaucheria submarina, Ulva rigida, Chlorophyceae, } \\
\text { Rhodophyceae }\end{array}$ & B \\
\hline Epiphytes & Ep & & B \\
\hline Phytoplankton & Phy & & $\mathrm{P}$ \\
\hline Bacterioplankton & $\mathrm{Ba}$ & & $\mathrm{P}$ \\
\hline Zooplankton & Zoo & Copepoda, Cladocera & $\mathrm{P}$ \\
\hline Micro-meiobenthos & Mi-Me & Protozoa, Nematoda, Copepoda & B \\
\hline Macrobenthos detritivorous & Md & Polychaeta, Amphipoda, Isopoda & B \\
\hline Macrobenthic herbivores & Mh & Amphipoda, Gastropoda & B \\
\hline Macrobenthos filter-feeders & Mff & Bivalvia (except Ruditapes philippinarum) & $\mathrm{B}$ \\
\hline Manila clam juv. & Rpj & Ruditapes philippinarum $<$ commercial size & B \\
\hline Manila clam adults & $\mathrm{Rp}$ & Ruditapes philippinarum $>$ commercial size & B \\
\hline Macrobenthos mixed-feeders & $\mathrm{Mmf}$ & Anthozoa, Decapoda & B \\
\hline Macrobenthos carnivorous & Mc & Decapoda, Gastropoda, Polychaeta & B \\
\hline C. crangon & $\mathrm{Cc}$ & Crangon crangon & B \\
\hline Mullet juv. & Muj & Mugilidae juveniles & $\mathrm{P}$ \\
\hline Mullet & $\mathrm{Mu}$ & Mugilidae & $\mathrm{P}$ \\
\hline Sand smelt & $\mathrm{Ab}$ & Atherina boyeri & $\mathrm{P}$ \\
\hline Pipefish & $\mathrm{Pi}$ & Syngnathidae & $\mathrm{P}$ \\
\hline Small gobies & $\mathrm{Sg}$ & Knipowitschia panizzae, Pomatoschistus spp. & $\mathrm{B}$ \\
\hline Grass goby juv. & Zoj & Zosterisessor ophiocephalus juveniles & B \\
\hline Grass goby & Zo & Zosterisessor ophiocephalus & B \\
\hline Nekton carnivorous & $\mathrm{Nc}$ & Solea solea, Sepia officinalis, Plathichthys flesus. & $\mathrm{P}$ \\
\hline Gilthead seabream juv. & Saj & Sparus aurata juveniles & $\mathrm{P}$ \\
\hline Gilthead seabream & $\mathrm{Sa}$ & Sparus aurata & $\mathrm{P}$ \\
\hline European seabass juv. & Dlj & Dicentrarchus labrax juveniles & $\mathrm{P}$ \\
\hline European seabass & $\mathrm{Dl}$ & Dicentrarchus labrax & $\mathrm{P}$ \\
\hline Piscivorous birds & $\mathrm{Pb}$ & $\begin{array}{l}\text { Chroicocephalus ridibundus, Larus melanocephalus, Larus } \\
\text { michahellis, Sterna hirundo, Sterna sandvicensis, Sterna } \\
\text { albifrons, Podiceps cristatus, Podiceps nigricollis }\end{array}$ & $\mathrm{P}$ \\
\hline Waders & Wa & Calidris alpina, Tringa totanus & $\mathrm{P}$ \\
\hline Water column detritus & WCD & $\begin{array}{l}\text { Dissolved and particulate detrital organic matter present } \\
\text { in the water column }\end{array}$ & \\
\hline Sediment detritus & SPD & $\begin{array}{l}\text { Fast degradable detrital organic matter deposited on the } \\
\text { upper layer of the sediment and dissolved in interstitial } \\
\text { waters }\end{array}$ & \\
\hline
\end{tabular}


diet proportions with values $>0.5 \%$. Overall, 968 constraints were added to the 60 mass balance relations, leading to a system of 1028 equations and inequalities to be solved for the 310 unknown flows.

In accordance with the objectives of the study, the perturbation analysis was carried out in respect to the fishery landings, of Rp, Mmf, Mv, Cc, Mu, Ab, Sg, Zo, Nc, Sa, Dl (for abbreviations see Table 1), which were imposed as data equations in the model. The model was coded as a set of Matlab ${ }^{\mathrm{TM}}$ scripts, including routines from the Optimization Toolbox ${ }^{\mathrm{TM}}$, supported by Excel ${ }^{\mathrm{TM}}$ spreadsheets.

\section{Results}

As described in the methodological section, the model was run 31 times. Each run provided a balanced solution, which is consistent with a different random extraction of the values of fishery landings, obtained as described in Section 2.1. The rest of the data set and the set of constraints were kept at their initial values. All results here presented are obtained by averaging the outputs of the ensemble of balanced solutions. Biomasses of the original thirty-two compartments and the energy flows across them are reported in Table 2 . In the following subsections, flows and compartments will be aggregated, in order to highlight the main features of ecosystem structure and functioning.

\subsection{Ecosystem functioning}

The most relevant features of the lagoon food web are summarized in Table 3, which presents a set of well known ecological indexes and compares them with the findings presented in Libralato et al. (2002) concerning two 27 compartment food web models, which were balanced for two typical habitat of the lagoon of Venice, namely bare-bottom clam fishing grounds and seagrass meadows. These models were constructed using a data set collected in the 1900s and balanced using the Ecopath software. Nonetheless, this study represent a good term of comparison, since the complexity of the food web structure is similar to the one adopted in the present work.

The total system throughput (TST), the overall production, the net primary production are slightly higher, but comparables, with the results presented in Libralato et al. (2002). As explained in Section 2.2, TST corresponds to the sum of energy flows in the ecosystem, and is an indicator of its activity. In the case of the Venice lagoon this activity is supported by a high net primary production. With respect to this, the mean value of our estimate, to which a high standard deviation is associated, exceeds of $50 \%$ the maximum production estimated by Libralato et al. (2002), and is 4 times higher than the primary production estimated by Leguerrier et al. (2003) for benthic and pelagic systems of the Brouage mudflat (conversion from mass to energy was carried out according to the average phytoplankton caloric content by Platt and Irwin (1973)).

Regarding the ratio primary production/total respiration, which is an indicator of the fate of assimilated food, the value calculated by the IM lies in between the two values reported by Libralato et al. (2002). On the contrary, total catches estimated by the present model are well below the value reported by Libralato et al. (2002) for the fraction of the lagoon occupied by $R$. philippinarum during the 1990s, and more similar to those estimated for seagrass meadow habitat. These differences in primary production and catches are confirmed by the value estimated by IM for the gross efficiency (catches/net primary production), which is below the lower boundary reported by Libralato et al. (2002).

\subsection{Energy flows across trophic levels}

In order to facilitate the understanding of the complex relationships among compartments, the original 32 ones were aggregated into four Trophic Levels, according to Eq. (2). The trophic level of each compartment is given in Table 2, last column, while the estimated biomasses and fluxes among trophic levels are represented in Fig. 2.

As one can see in Table 2, the EE for primary producers ranges between $29.8 \%$ and $51.4 \%$, which indicates that a large fraction of the organic matter synthesized is not directly conveyed to higher trophic levels through grazing, but first accumulates in detritus. In fact, primary producers mortality accounts for $189 \mathrm{~kJ} \mathrm{~m}^{-2} \mathrm{~d}^{-1}$, $97 \%$ of the whole ecosystem energy flows towards detritus. As a result, approximately $66 \%$ of the net primary production reaches WCD and SPD, meanwhile only 2\% is directly consumed by TL 2 . These findings are consistent with those reported in Libralato et al. (2002), who estimated that flows to organic detritus could account for between $55 \%$ and $83 \%$ of the net primary production. The results presented in Table 2 indicate that approximately $75 \%$ of this flow is accounted for by epiphytes, which transfer $3.1 \mathrm{~kJ} \mathrm{~m}^{-2} \mathrm{~d}^{-1}$ to higher trophic levels (production minus other mortality, minus export), compared with about $1 \mathrm{~kJ} \mathrm{~m}^{-2} \mathrm{~d}^{-1}$ which is channelled towards secondary production through the other four compartments of primary producers. Organic detritus, i.e. the sum of the WCD and SPD compartments, represent the most important source of energy for TL 2, which receives $13.63 \mathrm{~kJ} \mathrm{~m}^{-2} \mathrm{~d}^{-1}$. Total consumption for TL 2, $21.4 \mathrm{~kJ} \mathrm{~m}^{-2} \mathrm{~d}^{-1}$, mainly results from grazing on organic detritus and TL $1.64 \%$ of the energy which enters TL 2 is lost from the system through respiration and 26\% goes to organic detritus. Energy reaching TL 3 is less than $3 \%$ of the energy which enters TL 2 . This ratio decreases even more between TL 4 and TL 3, 0.2\%. For TLs 2-4, approximately $60 \%$ of the energy consumed is lost from the system through respiration. Also, this ratio is close to those reported for the two habitats studied by Libralato et al. (2002) (TLs 2-4), ranging between $41 \%$ and $67 \%$. Fluxes to detritus from TLs $2-4$, which are composed by egestion and other mortality, range between $26 \%$ and $35 \%$, compared to the $30-67 \%$ reported by Libralato et al. (2002).

\subsection{Benthic pelagic coupling and energy losses}

Key energy flows between benthic and pelagic food webs are represented in Fig. 3. The attribution of different compartments to each food web is reported in Table 1 . As one can see, $99 \%$ of the total primary production occurs in the benthic sub-system. The key role of benthic producers in the food web of shallow water systems was already discussed by Leguerrier et al. (2003) for the Brouage mudflat. These authors estimated a production 5.2 times higher in the benthic system compared to the pelagic one, by considering only productions by phytoplankton and microphytobenthos compartments. From feeding preferences reported in Appendix E and fluxes reported in Table 2, one can compute the single predation fluxes. Macrobenthic herbivores account for $68 \%$ of microphytobenthos grazing, nearly $100 \%$ of seagrasses grazing, and $64 \%$ of macroalgae grazing. However, according to IM results, a very high fraction of benthic primary production, $52 \%$, is not grazed directly and goes to SPD. Micro and meiobenthos compartment result as the major consumers of SPD ( $88 \%$ of total consumption). Only $0.2 \%$ of the energy flowing from benthic PPs to SPD is directly transferred from the benthic to the pelagic food-web, through consumption by mullets. The remaining fraction enters the pelagic food web through resuspension, $5.14 \mathrm{~kJ} \mathrm{~m}^{-2} \mathrm{~d}^{-1}$, and predation of benthic detritivores and grazing by benthic herbivores.

Sedimentation of WCD, $28.9 \mathrm{~kJ} \mathrm{~m}^{-2} \mathrm{~d}^{-1}$, represents the most important exchange of energy from the pelagic towards the benthic food web. Important flows in the same direction are associated with WCD and phytoplankton grazing by filter feeders. In particular, this energy sustains the important stock of Manila clam, which feeds mostly on WCD, but is also the main con- 
D. Brigolin et al. / Ecological Modelling 222 (2011) 2404-2413

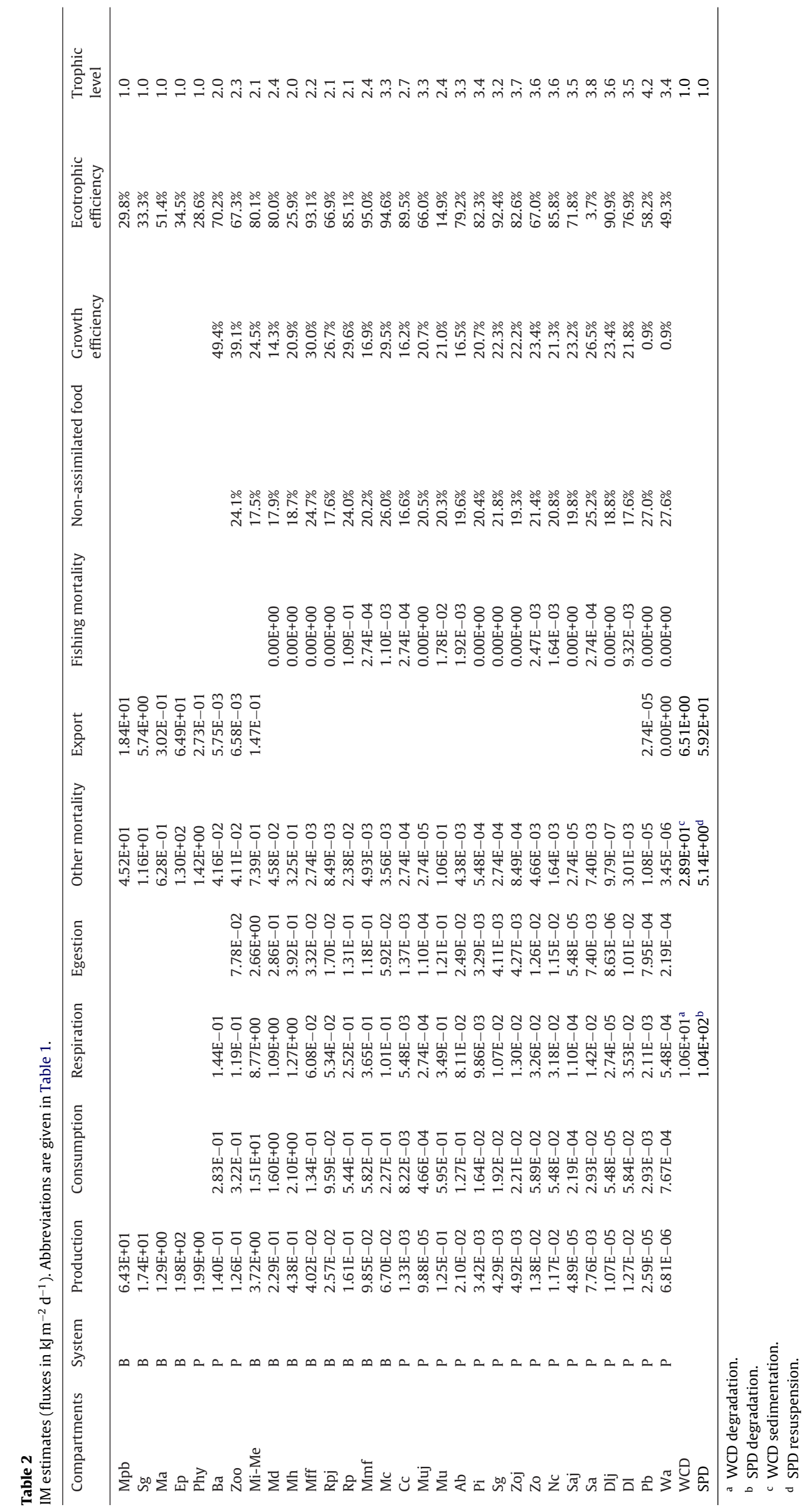


Table 3

Comparison between a set of ecological indicators based on IM final solution and those reported by a Venice lagoon Ecopath model based on data from the 1990s.

\begin{tabular}{lll}
\hline & IM solution & Libralato et al. (2002) \\
\hline Total system throughput $\left(\mathrm{kJ} \mathrm{m}^{-2} \mathrm{~d}^{-1}\right)$ & 532.92 & $357.20-422.58$ \\
Sum of all production $\left(\mathrm{kJ} \mathrm{m}^{-2} \mathrm{~d}^{-1}\right)$ & $288.18 \pm 208.66$ & $109.57-217.35$ \\
Total net primary production $\left(\mathrm{kJ} \mathrm{m}^{-2} \mathrm{~d}^{-1}\right)$ & $282.94 \pm 208.88$ & $72.98-189.73$ \\
Total primary production/total respiration $(-)$ & 2.2 & $1.1-3.1$ \\
Total catches $\left(\mathrm{kJ} \mathrm{m}^{-2} \mathrm{~d}^{-1}\right)$ & $0.14 \pm 0.01$ & $0.11-7.03$ \\
Gross efficiency $($ catch/net primary production) $(-)$ & 0.0005 & $0.0006-0.0963$ \\
\hline
\end{tabular}
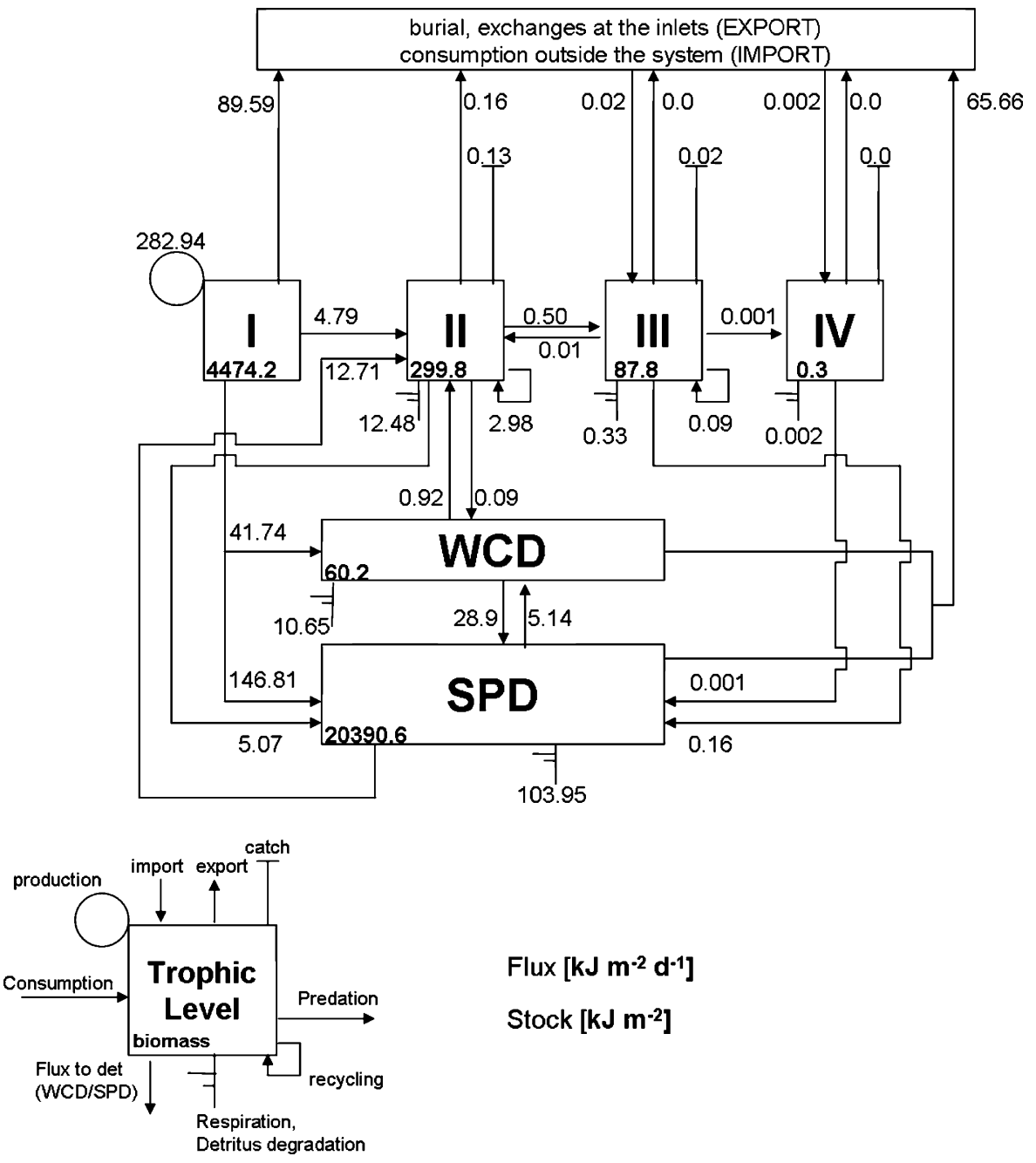

\section{Flux $\left[\mathrm{kJ} \mathrm{m}^{-2} \mathbf{d}^{-1}\right]$}

Stock [kJ m-2]

Fig. 2. Estimated fluxes $\left(\mathrm{kJ} \mathrm{m}^{-2} \mathrm{~d}^{-1}\right)$ and observed biomasses $\left(\mathrm{kJ} \mathrm{m}^{-2}\right)$ aggregated by trophic level.

sumer of phytoplankton (53\% of the total grazing exerted on this compartment).

Fig. 3 also shows that a relevant fraction of energy is lost from the system through three different mechanisms. Approximately $23 \%$ and $59 \%$ of the energy entering WCD and SPD is lost through microbially mediated organic matter oxidation. The export of WCD which mainly happens through exchanges at the inlets is about $6.5 \mathrm{~kJ} \mathrm{~m}^{-2} \mathrm{~d}^{-1}$, approximately $14 \%$ of the energy entering WCD. Finally, $59.16 \mathrm{~kJ} \mathrm{~m}^{-2} \mathrm{~d}^{-1}$ of SPD, i.e. $34 \%$ of the energy entering SPD, is exported through burial in deeper sediments.

\section{Discussion}

This section focuses on two issues: (1) specific advantages and limitations of this application of the IM methodology are highlighted; (2) the ecological results are discussed in relation to those obtained in recent attempts at modelling the Venice lagoon food web, showing how food web model could be used for detecting significant changes in ecosystem structure and functioning.

\subsection{Performance of IM methods}

As said in the methodological section, the Minimum Norm, MN, method criterion applied in this study seeks to minimize both the sum of squared energy flows and squared residual errors $\varepsilon$, consistently with the constraints. In this application, the sum of squared flows ranged between $4.78 \times 10^{9}$ and $3.74 \times 10^{11}$ and the sum of squared residuals between $4.4 \times 10^{-16}$ and $1.2 \times 10^{-14}$. Such small residuals indicate that all inverse solutions, besides being consistent with the set of ecological constraints, are almost perfectly balanced: therefore, they are all steady-state representations of the flows, in relation to each set of landings, selected using the perturbation method. 


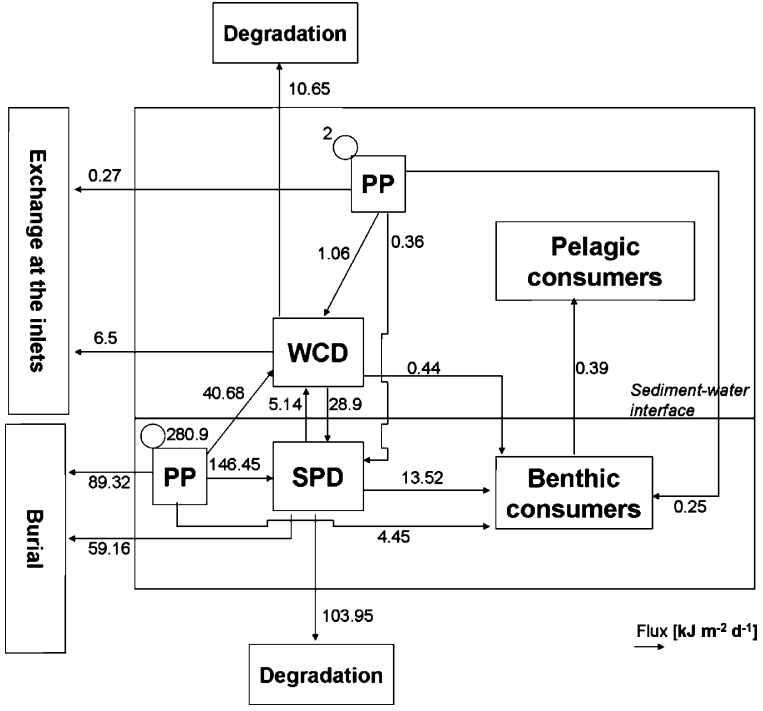

Fig. 3. Most important energy fluxes $\left(\mathrm{kJ} \mathrm{m}^{-2} \mathrm{~d}^{-1}\right)$ between benthic and pelagic systems.

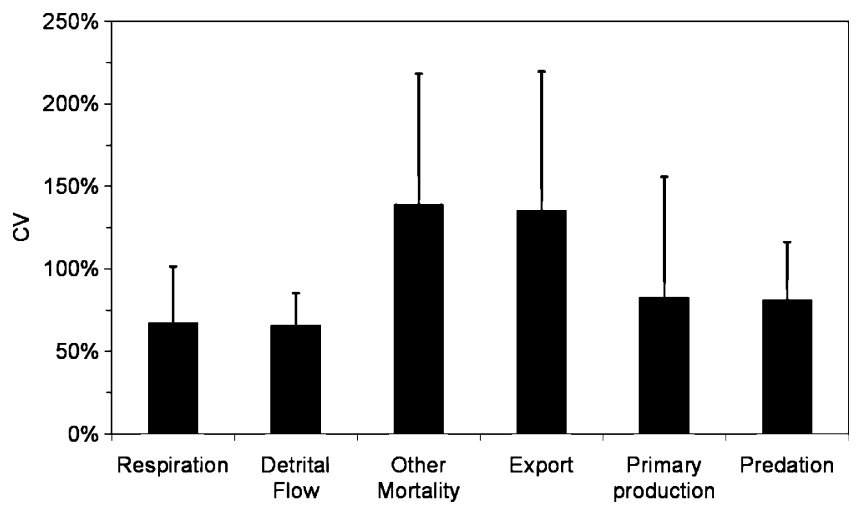

Fig. 4. Coefficients of variation of the estimated flows, calculated on the ensemble of synthetic solutions.

To this regard, it is interesting to note that the perturbation method gives the possibility of estimating the uncertainty in the estimated flows, with respect to the uncertainties in input data for landings. The results, expressed in terms of CVs, are shown in Fig. 4 for the most important flows. Production and consumption flows present $\mathrm{CV}$ s around 50\%. On the other hand, export and other mortality show CVs higher than $100 \%$, indicating that model results for these groups of flows are the most sensitive to changes in landing input data. These findings suggest that a more accurate estimation of the landings would have markedly increase the confidence in the estimation of the other export terms and mortality causes, while the estimates of production and consumption are more robust.
Besides providing useful information about the uncertainties in flow estimates, the perturbation method here adopted proved to be effective in overcoming one of the main shortcoming of the MN inversion. In fact, as pointed out in Vézina et al. (2004), this method can run into problems when there are alternative pathways to biomass export from a given compartments, which are not strongly constrained. In such situations, the MN solution leads to allocate all the export in one flow, at the expenses of the others. The overall effect is that many flows are bound to either their upper or lower limits (sticky constraints or active constraints). A large number of active constraints suggests that the optimum may not have been found and that the solution was determined by a priori bounds rather than by patterns in the data.

The implementation of the perturbation method in this study proved to be effective in coping with this problem, as one can see from the results presented in Table 4, which shows the number of active constraints, concerning the main flows and efficiencies, for the nominal solution and the average of the ensemble of synthetic solutions. As one can see, the average of the ensemble of synthetic solutions presents a much lower percentage of total active constraints compared to the nominal solution, for all main flows and efficiencies. With respect to the total number of flows, the percentage of active constraints decreases from $69 \%$ to $5 \%$. This finding indicates that the average of synthetic solutions, which was presented in detail in the previous section, provides a picture of the ecosystem flows at steady state which is nearly insensitive to the constraints and, therefore, does not heavily depend on our choice of the ranges for the inequalities. Therefore, the combination of the MN criterion with the perturbation method proved to be effective for obtaining a meaningful representation of the flows, even though alternative Monte-Carlo based methods, such as that proposed in Kones et al. (2009), could represent a better alternative an certainly deserves to be tested.

From a methodological aspect, it is also important to note that the adoption of the weighting scheme allowed to explicitly include in the network the juveniles of Manila clam, mullets, grass goby, gilthead seabream and European seabass. In spite of large differences among the biomasses of juveniles and those of adult compartments (2-3 orders of magnitude), juveniles represent a source of food for nekton carnivorous, gilthead seabream, European seabass and piscivorous birds. With respect to this issue, additional insights can be obtained by straightforwardly applying the weighting methodology adopted here, for constructing specific food web models for different Venice lagoon nursery areas, using the same number of compartments.

\subsection{Recent changes in the Venice lagoon food web}

The results presented in the previous section show that the main patterns of the energy flows across the Venice lagoon ecosystem are, in general, consistent with those estimated in previous

Table 4

Number of active constraints for different parameters (estimates at the limit set by the constraints). Only the estimates based on the upper and lower constraint limits are used here (see Appendix C in supporting material online). Nominal solution: first inversion without perturbation; average of the ensemble of synthetic solutions: mean of 31 balanced iterations. $P_{i}$ : production, $Q_{i}$ : consumption, $R_{i}$ : respiration, $\mathrm{GS}_{i}\left(=1-\mathrm{AE}_{i}\right)$ : proportion of food not assimilated, $\mathrm{GE}_{i}$ : growth efficiency, $\mathrm{EE}_{i}$ : ecotrophic efficiency, $\mathrm{DC}_{u \rightarrow y}$ : proportion of prey $u$ in diet (by mass) of consumer $y, D_{i}, M_{i}$ ratios: constraints based on mortality or egestion ratios, $E x_{i}$ : export outside the system.

\begin{tabular}{|c|c|c|c|c|c|c|c|c|c|c|}
\hline & \multicolumn{10}{|c|}{ Flow/efficiency } \\
\hline & $P_{i}$ & $Q_{i}$ & $R_{i}$ & $\mathrm{GS}_{i}$ & $\mathrm{GE}_{i}$ & $\mathrm{EE}_{i}$ & $\mathrm{DC}_{u \rightarrow y}$ & $D_{i}, M_{i}$ ratios & $E x_{i}$ & Total \\
\hline \multicolumn{11}{|l|}{ Nominal solution } \\
\hline Number of active constraints & 6 & 6 & 0 & 21 & 17 & 14 & 145 & 10 & 9 & 228 \\
\hline Number of total estimates & 30 & 24 & 2 & 24 & 25 & 30 & 173 & 10 & 12 & 330 \\
\hline$\%$ of active constraints & $20 \%$ & $25 \%$ & $0 \%$ & $88 \%$ & $68 \%$ & $47 \%$ & $84 \%$ & $100 \%$ & $75 \%$ & $69 \%$ \\
\hline \multicolumn{11}{|c|}{ Average of the ensemble of synthetic solutions } \\
\hline Number of active constraints & 0 & 1 & 0 & 0 & 1 & 1 & 10 & 2 & 1 & 16 \\
\hline Number of total estimates & 30 & 24 & 2 & 24 & 25 & 30 & 173 & 10 & 12 & 330 \\
\hline$\%$ of active constraints & $0 \%$ & $4 \%$ & $0 \%$ & $0 \%$ & $4 \%$ & $3 \%$ & $6 \%$ & $20 \%$ & $8 \%$ & $5 \%$ \\
\hline
\end{tabular}


attempts and, in particular, in Libralato et al. (2002), which were based on data collected in the 1990s. The two models, however, present some differences, in particular concerning the role of the detritus. In our work, organic detritus is divided into two compartments, in order to gain a deeper understanding of the role of the fraction suspended in the water column, WCD, and dispersed in the surface sediment, SPD. Based on the results presented in Libralato et al. (2002) the detritus compartment in the seagrass habitat, which is more representative of the whole lagoon, was not at steady-state and was accumulating energy at a rate of $3712 \mathrm{~kJ} \mathrm{month}^{-1} \mathrm{~m}^{-2}$, while the detritus stock was $13,743 \mathrm{~kJ} \mathrm{~m}^{-2}$. As said above, the inverse model methodology here adopted provided steady-state solutions nearly perfectly balanced and yielded an higher estimate of the detritus stock, about $20,390 \mathrm{~kJ} \mathrm{~m}^{-2}$, which can be considered as representative of the average lagoon ecosystem in the years 2003-05: this seems to confirm that the lagoon ecosystem and, in particular, seagrass meadows, which, nevertheless, covers more than $10 \%$ of the total lagoon surface, at the end of the last decade was accumulating energy in the sediment compartment.

However, the most important difference concerns the fraction of the detritus stock that is recycled by the ecosystem and channelled towards higher trophic levels, which is about $0.0007 \mathrm{~d}^{-1}$, versus the $0.007 \mathrm{~d}^{-1}$ estimated by Libralato et al. (2002). The lower detritus consumption may indicate that the ecosystem was responding to changes in nutrient loads and in sediment re-suspension pattern, by altering the composition of the primary producers community. This finding is consistent with the results presented in Solidoro et al. (2010), which indicates a marked decrease in phytoplankton concentrations and an increase in the extension of seagrass meadows during the last decade. To this regard, it is interesting to note that the model predicts a very large epiphytes production, which represents almost $70 \%$ of the net primary production. This can be an artefact of the method used for the estimation of their biomass, which assumed a constant value for seagrass shoots coverage, but can also suggest that this community may be playing a crucial role in sustaining the macrobenthos compartments and, indirectly, the benthic filter feeders, which take most of their energy requirements from the WCD compartment. In fact, Fig. 3 shows that the main input for $W C D, 40.68 \mathrm{~kJ} \mathrm{~m}^{-2} \mathrm{~d}^{-1}$, is given by the energy transferred from benthic primary producers, due to resuspension processes: this energy flow is mainly accounted for by the mortality of epiphytes.

The low rate of recycling of the sediment detritus stock may also be related to our assumption about the composition of the two detritus pools, which are characterized by the same degradation rate. Since a large fraction of lagoon SPD is composed by dead tissues of primary producers, which can be characterized by extremely different degradation rates, such hypothesis is certainly questionable. According to model results, $90 \%$ of the detritus pools is composed by dead epiphytes and microphytobenthos, presenting a degradation rate similar to phytoplankton, which makes them readily available for detritivores. Only $8 \%$ of the SPD pool is composed by dead seagrasses, which degradation rate is 5 times lower than the phytoplankton one (Plus et al., 2003). Therefore, the effective availability of energy for sustaining detritivores, such as mullets, which get $50 \%$ of the energy requirement from SPD, see Appendix E, is likely to be realistic. Nonetheless, site-specific data on the organic matter composition and degradability would certainly enhance the accuracy of IM estimation of feeding relations and could be incorporated in the model by including additional constraints.

Model results also indicate that the energy flow sustaining TL 2 , see Fig. 2, is about one sixth of that estimated in Libralato et al. (2002); this means that, in general, less energy is available for higher trophic levels, which include fishery target species. In spite of that, the ratio between fishing mortality and energy consumed by target species showed a decrease for mullets, $2.9 \%$, grass goby, $4.1 \%$, and nekton carnivorous, $2.9 \%$, in respect to the values given in Carrer and Opitz (1999), who, based on data from the 1990s, estimated for fish compartments ratios equal to $6.5 \%$ and $4.4 \%$. Such a decrease, agrees with the general trend observed by Pellizzato et al. (2006). These authors reported a progressive decline of traditional fishery in the lagoon during the 1990s, mainly caused by the decreasing social and economic value attributed by the local population to this activity. The only exception to this trend is given by the European seabass, for which a ratio of $15 \%$ was estimated. However, this finding is very likely to be attributed to a biased estimation of the catches from market data due to the poor knowledge about the catches of recreational fishery and the difficulty in separating aquaculture and fishery production.

\section{Conclusions}

A food web mass balance model for the lagoon of Venice was developed by applying an inverse methodology of flux estimation to a comprehensive set of site specific field data, most of which were collected during the 2003 spring-summer. A Montecarlo approach, based on random perturbations of landings data, allowed to assess the uncertainty in the estimated energy flows in response to the uncertainties of input data. Model results indicate that pathways of energy flow across the trophic network are, in general, consistent with those estimated by previous model developed for the same area, which were based on data from the 1990s. With respect to the results obtained by previous models the system presents an higher productivity, most of which happens in the benthic compartment, and is in part exported from the system through burial and organic matter oxidation. As a consequence, the inverse model predicts a lower amount of energy transferred from detritus to consumers, compared to the estimations obtained by previous attempts. Regarding the anthropic pressure on the ecosystem, IM results indicate a general decrease in catches by traditional fishery compared to previous models, which confirm a general trend reported for the sector by independent studies. From the methodological standpoint, the IM, which is based on an objective least-squares criterion for constrained optimization, and is capable to quantify uncertainty in the results, is likely to be an useful approach for both research and management purposes in the lagoon. The weighting scheme adopted allowed to include in the network compartments with low energy stocks. With respect to this issue, a separate representation of different lagoon macrohabitats, would help in resolving specific aspects of the structure and functioning of the Venice lagoon ecosystem, such as the role of juveniles.

\section{Appendix A. Supplementary data}

Supplementary data associated with this article can be found, in the online version, at doi:10.1016/j.ecolmodel.2011.04.002.

\section{References}

ARPAV, 2007. Bacino Scolante nella Laguna di Venezia. Rapporto sullo stato ambientale dei corpi idrici Anni 2003-2004, 16 pp. ISBN 88-7504-112-1.

Ass. Faunisti Veneti, 2004. Atlante faunistico della Provincia di Venezia. Provincia di Venezia-Associazione Faunisti Veneti, Castrocielo (FR), 257 pp.

Auteri, R, Abella, A, Baino, R., Righini, P., Serena, F, Silvestri, R., Volani, A. 1993. Interazioni trofiche e attività di pesca nella laguna di Orbetello. Cons. Reg. Idrobiol. Pesca 6, 1-222.

Belgrano, A., Scharler, U.M., Dunne, J., Ulanowicz, R.E., 2005. Aquatic Food Webs: An Ecosystem Approach. Oxford University Press, 272 pp.

Brey, T., 2001. Population dynamics in benthic invertebrates. A Virtual Handbook. Version 01.2. Alfred Wegener Institute for Polar and Marine Research, Germany Available from: http://www.awi-bremerhaven.de/Benthic/Ecosystem/FoodWeb/Handbook/main.html. 
Buia, M.C., Gambi, M.C., Zupo, V., 2000. Structure and functioning of Mediterranean seagrass ecosystems: an overview. Biol. Mar. Medit. 7, 167-190.

Bundy, A., 2005. Structure and function of the eastern Scotian shelf Ecosystem before and after the groundfish collapse in the early 1990s. Can. J. Fish. Aquat. Sci. 62, 1453-1473.

Carrer, S., Opitz, S., 1999. Trophic network model of a shallow water area in the northern part of the Lagoon of Venice. Ecol. Model. 124, 193-219.

Carrer, S., Halling-Sørensen, B., Bendoricchio, G., 2000. Modelling the fate of dioxins in a trophic network by coupling an ecotoxicological and an Ecopath model. Ecol. Model. 126, 201-223.

Cavraro, F., 2007. La comunità meiobentonica lagunare: variazioni nella funzionalità a seguito di eventi di disturbo sperimentale. M.Sc. thesis, Ca' Foscari University of Venice, $60 \mathrm{pp}$.

Celussi, M., Pugnetti, A., Del Negro, P., 2009. Structural dynamics of bacterioplankton assemblages in the Lagoon of Venice. Estuar. Coast. Shelf Sci. 84, 154-160.

Christensen, V., Pauly, D., 1992. Ecopath II-a software for balancing steady-state ecosystem models and calculating network characteristics. Ecol. Model. 61, 169-185.

Coll, M., Santojanni, A., Arneri, E., Palomera, I., Tudela, S., 2007. An ecosystem model of the Northern and Central Adriatic Sea: analysis of ecosystem structure and fishing impacts. J. Mar. Syst. 67, 119-154.

Consorzio Venezia Nuova, 2003. Indagini sperimentali sui rilasci dei sedimenti e biodisponibilità dei microinquinanti. Technical report, 209 pp. (in Italian).

Consorzio Venezia Nuova, 2005a. Ciclo annuale e composizione tassonomica dei popolamenti planctonici nella laguna di Venezia (aprile 2003-marzo 2004) ICSREL-T039.0. Technical report, 96 pp. (in Italian).

Consorzio Venezia Nuova, 2005b. Rilievo della distribuzione delle comunità bentoniche di substrato molle (macro e meiozoobenthos e macrofitobenthos) in Laguna di Venezia (2002-2003-2004). Technical report, 165 pp. (in Italian).

Corila, 2009. Campagne periodiche di misura, negli anni 2007 e 2008, della qualità delle acque in collaborazione con il SAMA. Technical report, 96 pp. (in Italian).

Costanza, R., d'Arge, R., de Groot, R., Farberk, S., Grasso, M., Hannon, B., Limburg, K., Naeem, S., O'Neill, R.V., Paruelo, J., Raskin, R.G., Sutton, P., van den Belt, M., 1997. The value of the world's ecosystem services and natural capital. Nature 387, 253-260.

Cucco, A., Umgiesser, G., 2006. Modeling the Venice Lagoon residence time. Ecol. Model. 193, 34-51.

Danovaro, R., Fabiano, M., 1997. Seasonal changes in quality and quantity of food available for benthic suspension-feeders in the Golfo Marconi (North-western Mediterranean). Estuar. Coast. Shelf Sci. 44, 723-736.

Facca, C., Sfriso, A., 2007. Epipelic diatom spatial and temporal distribution and relationship with the main environmental parameters in coastal waters. Estuar. Coast. Shelf Sci. 75, 35-49.

Facca, C., Bazzoni, A.M., Ceoldo, S., Hewes, C., Holm-Hansen, O., Sfriso, A., Socal, G., 2009. Interazione acqua-sedimento: le microalghe della laguna di Venezia. In: $40^{\circ}$ Congress of the Italian Marine Biology Association , Livorno, May 26-29, 2009.

Franco, A., Franzoi, P., Malavasi, S., Riccato, F., Torricelli, P., 2006a. Fish assemblages in different shallow water habitats of the Venice Lagoon. Hydrobiologia 555, 159-174.

Franco, A., Franzoi, P., Malavasi, S., Riccato, F., Torricelli, P., Mainardi, D., 2006b. Use of shallow water habitats by fish assemblages in a Mediterranean coastal lagoon. Estuar. Coast. Shelf Sci. 66, 67-83.

Franzoi, P., Maio, G., Pellizzato, M., Zucchetta, M., Franco, A., Georgalas, V., Fiorin, R. Riccato, F., Buratto, T., Rossi, R., Torricelli, P., 2005. Messa a punto di metodologie innovative applicabili alla valutazione del novellame da allevamento. Nuovi metodi ecologici per la valutazione del reclutamento e della distribuzione del novellame di orata, spigola e mugilidi ai fini della gestione sostenibile di ecosistemi lagunari. Ministero per le politiche agricole e forestali - Direzione Generale della Pesca e dell'Acquacoltura - VI Piano Triennale della pesca e dell'acquicoltura in acque marine e salmastre, $129 \mathrm{pp}$.

Franzoi, P., Franco, A., Torricelli, P., 2010. Fish assemblage diversity and dynamics in the Venice lagoon. Rendiconti Lincei 21, 269-281.

Froese, R., Pauly, D. (Eds)., 2002. FishBase. World Wide Web electronic publication [On line: September 2002] <http://www.fishbase.org/search.php> (Web pages accessed April 2009)

Gačić, M., Kovačević, V., Mancero Mosquera, I., Mazzoldi, A., Cosoli, S., 2005. Water fluxes between the Venice Lagoon and the Adriatic Sea. In: Fletcher, C.A., Spencer, T. (Eds.), Flooding and Environmental Challenges for Venice and its Lagoon: State of Knowledge. Cambridge University Press, Cambridge, pp. 431-444.

http://statistica.regione.veneto.it. Veneto Region Statistics Database (accessed December 2010).

Jørgensen, S.E., Nielsen, S.N., Jørgensen, L.A., 1991. Handbook of Ecological Parameter and Ecotoxicology. Elsevier, Amsterdam.
Kones, J.K., Soetaert, K., van Oevelen, D., Owino, J.O., 2009. Are network indices robust indicators of food web functioning? A Monte Carlo approach. Ecol. Model. 220, 370-382.

Leguerrier, D., Niquil, N., Boileau, N., Rzeznik, J., Sauriau, P.-G., Le Moine, O., Bacher, C., 2003. Numerical analysis of the food web of an intertidal mudflat ecosystem on the Atlantic coast of France. Mar. Ecol. Prog. Ser. 246, 17-37.

Libralato, S., Pastres, R., Pranovi, F., Raicevich, S., Granzotto, A., Giovanardi, O., Torricelli, P., 2002. Comparison between the energy flow networks of two habitats in the Venice Lagoon. Mar. Ecol. 23, 228-236.

Libralato, S., Solidoro, C., 2009. Bridging biogeochemical and food web models for an End-to-End representation of marine ecosystem dynamics: the Venice lagoon case study. Ecol. Model. 220, 2960-2971.

Lindeman, R.L., 1942. The trophic-dynamic aspect of ecology. Ecology 23, 399-418.

Morissette, L., Castonguay, M., Savenkoff, C., Swain, D.P., Chabot, D., Bourdages, H., Hammill, M.O., Hanson, J.M., 2009. Contrasting changes between the northern and southern Gulf of St. Lawrence ecosystems associated with the collapse of groundfish stocks. Deep Sea Res. II 56, 2117-2131.

Pellizzato, Favretto, J., Galvan, T., Penzo, P., 2006. Produzione alieutica in laguna di Venezia. Biol. Mar. Medit. 13, 897-900.

Platt, T., Irwin, B., 1973. Caloric content of phytoplankton. Limnol. Oceanogr. 18, 306-309.

Plus, M., Chapelle, A., Ménesguen, A., Deslous-Paoli, J.M., Auby, I., 2003. Modelling seasonal dynamics of biomasses and nitrogen contents in a seagrass meadow (Zostera noltii Hornem.): application to the Thau lagoon (French Mediterranean coast). Ecol. Model. 161, 213-238.

Pranovi, F., Libralato, S., Raicevich, S., Granzotto, A., Pastres, R., Giovanardi, O., 2003. Mechanical clam dredging in Venice Lagoon: ecosystem effects evaluated with a trophic mass-balance model. Mar. Biol. 143, 393-403.

Savenkoff, C., Castonguay, M., Vézina, A.F., Despatie, S.-P., Chabot, D., Morissette, L., Hammill, M.O., 2004. Inverse modelling of trophic flows through an entire ecosystem: the northern Gulf of St. Lawrence in the mid-1980s. Can. J. Fish. Aquat. Sci. 61, 2194-2214.

Savenkoff, C., Castonguay, M., Chabot, D., Hammill, M.O., Bourdages, H., Morissette, L., 2007a. Changes in the northern Gulf of St. Lawrence ecosystem estimated by inverse modelling: evidence of a fishery-induced regime shift? Estuar. Coast. Shelf Sci. 73, 711-724.

Savenkoff, C., Swain, D.P., Hanson, J.M., Castonguay, M., Hammill, M.O., Bourdages, $\mathrm{H}$. Morissette, L., Chabot, D., 2007b. Effects of fishing and predation in a heavily exploited ecosystem: comparing periods before and after the collapse of groundfish in the southern Gulf of St. Lawrence (Canada). Ecol. Model. 204, $115-128$.

Sfriso, A., Facca, C., 2007. Distribution and production of macrophytes and phytoplankton in the lagoon of Venice: comparison of actual and past situation. Hydrobiologia 577, 71-85.

Sfriso, A., Ghetti, P.F., 1998. Seasonal variations in the biomass, morphometric parameters and production of rhizophytes in the lagoon of Venice. Aquat. Bot. 61, 207-223.

Sfriso, A., Facca, C., Marcomini, A., 2005. Sedimentation rates and erosion processes in the lagoon of Venice. Environ. Int. 31, 983-992.

Solidoro, C., Bandelj, V., Bernardy Aubry, F., Camatti, E., Ciavatta, S., Cossarini, G., Facca, C., Franzoi, P., Libralato, S., Melaku Canu, D., Pastres, R., Pranovi, F., Raicevich, S., Socal, G., Sfriso, A., Sigovini, M., Tagliapietra, D., Torricelli, P., 2010. Response of the Venice lagoon ecosystem to natural and anthropogenic pressures over the last 50 years. In: Kennish, M.J., Paerl, H.W. (Eds.), Coastal Lagoons, Critical Habitats of Environmental Change. CRC Press, pp. 483-511.

Sorokin, Y.I., Giovanardi, O., 1995. Trophic characteristics of the Manila clam (Tapes philippinarum Adams and Reeve). ICES J. Mar. Sci. 52, 853-862.

Tagliapietra, D., Cornello, M., Pessa, G., 2007. Indirect estimation of benthic secondary production in the Lagoon of Venice (Italy). Hydrobiologia 588, 205-212.

Ulanowicz, R.E., 1986. Growth and Development: Ecosystem Phenomenology. Springer, New York, 203 pp.

Venice Water Authority, 2010. Stato dell'ecosistema lagunare Veneziano. Marsilio, 290 pp.

Vézina, A.F., Berreville, F., Lozab, S., 2004. Inverse reconstructions of ecosystem flows in investigating regime shifts: impact of the choice of objective function. Prog. Oceanogr. 60, 321-341.

Vézina, A.F., Savenkoff, C., 1999. Inverse modeling of carbon and nitrogen flows in the pelagic food web of the northeast subarctic Pacific. Deep Sea Res. II 46, 2909-2939.

Vézina, A.F., Pace, M.L., 1994. An inverse model analysis of planktonic food webs in experimental lakes. Can. J. Fish. Aquat. Sci. 51, 2034-2044.

Vézina, A.F., Platt, T., 1988. Food web dynamics in the ocean. I. Best-estimates of flow networks using inverse methods. Mar. Ecol. Prog. Ser. 42, 269-287.

Winberg, G.G., 1956. Rate of metabolism and food requirements of fish. Fish. Res. Board Can. Trans. Ser., 194. 